\title{
Putative RNA-Binding Protein 15
}

National Cancer Institute

\section{Source}

National Cancer Institute. Putative RNA-Binding Protein 15. NCI Thesaurus. Code C97295.

Putative RNA-binding protein 15 (977 aa, $107 \mathrm{kDa}$ ) is encoded by the human RBM15 gene. This protein plays a role in RNA binding. 